\title{
Application of Cooperative Learning Jigsaw Type to Improve Learning Outcomes of Economic Introduction and Business
}

\author{
Nurrin Fadilla Rokhmah', Waspodo Tjipto Subroto ${ }^{2}$
}

\begin{tabular}{l} 
ARTICLE INFO \\
\hline Article History: \\
Received 10.10.2018 \\
Received in revised form \\
24.01 .2019 \\
Accepted \\
Available online 01.04 .2019
\end{tabular}

\begin{abstract}
This study aims to analyze the improvement of student learning outcomes by applying the jigsaw ty pe cooperative learning model on the introductory subjects of economics and business basic competence of production costs. This research is a Classroom Action Research. Subjects and location is the students of class X Accounting 3 SMK Sejahtera Surabay a. Learning tools consist of syllabus, Learning Implementation Plan, learning material, Student Worksheet, and post test sheet. While the instrument used is a student observation sheet. The results showed that student activity increased $9.52 \%$ from cycle I $76.19 \%$ to $85.71 \%$ in cycle II. Students classical completeness inc reased by $16.22 \%$ from cycle I $64.86 \%$ to $81.08 \%$ in cycle II. It shows that jigsaw ty pe cooperative learning model can improve learning outcomes on introductory subjects of economics and business students of class $\mathrm{X}$ Accounting 3 SMK Sejahtera Surabaya.
\end{abstract}

Keywords:

(C) 2019IJERE. All rights reserved

Learning outcomes, cooperative learning, jigsaw.

\section{INTRODUCTION}

Learning model is one of the ways teachers use to achieve learning objectives. To achieve a learning goal teachers do not have to use only one method, but teachers can use different learning methods in accordance with learning materials. Through the learning model the teacher can help students to get information, ideas, skills, ways of thinking and expressing their ideas (Suprijono, 2011: 46).

Cooperative learning Jigsaw type is one type of cooperative learning that encourages students to actively and mutually help fellow group members in mastering learning materials to achieve maximum performance (Isjoni, 2010: 54). In this Jigsaw learning model students have many opportunities to explore the subject matter of their respective expert teams and recount information from previously unearthed learning materials on expert teams to the original team. Hamalik (2008:114) learning outcome is a change in behavior in a person that can be observed and measured in the form of knowledge, attitude and skills. The change in question is an increase and development in students who initially did not know to know. The change is accompanied by an increase in understanding, habits, and skills.

Based on the preliminary study, the condition of learning process in class X Accounting 3 SMK Sejahtera Surabaya is still less conducive. Not many students can focus on the material being taught. Students tend to talk with their friends, listen to music and play mobile phones, and fall asleep during the learning process. This is because students are only given lecture methods on most of the material taught as well as on other subjects that make students bored and have no motivation to focus on the material. Where one of the weaknesses of the lecture method is the difficulty of knowing whether all students already understand the material being taught or not (Sanjaya, 2006: 148). So that the learning results obtained have not been satisfactory because they have not met the minimum graduation standard.

In the cooperative learning model the teacher conveys the learning objectives and motivates students and the teacher presents information through media or learning resources. Based on research conducted by Janah (2019), student learning outcomes in the experimental class $1 \mathrm{with}$ cooperative learning models have a smaller average value which is equal to 74.75 compared to the learning outcomes of experimental class 2 students with inquiry learning models with an average value of 77.00. This attracted the interest of researchers to apply the jigsaw ty pe cooperative learning model to improve learning outcomes.

Based on the above problems it is necessary to conduct research entitled "Application of Cooperative Learning Jigsaw Type to Improve Learning Outcomes Economics Introduction and Business Students Class X

\footnotetext{
Corresponding e-mail: nurrinfadillar@gmail.com ; orcid.org/0000-0003-0508-439X

2 Corresponding e-mail: waspodosubroto@unesa.ac.id ; orcid.org/0000-0002-1477-1653

Postgraduate Universitas Negeri Surabaya ${ }^{1}$, Postgraduate Universitas Negeri Surabaya ${ }^{2}$
} 
Accounting 3 SMK Sejahtera Surabaya Lesson Year 2016/2017". The purpose of this research are as follows: (1) To analyze student activity in applying cooperative type jigsaw learning model on introductory subjects of economics and business class X students Accounting 3 SMK Sejahtera Surabaya in academic year 2016/2017. (2) To analyze the improvement of student learning outcomes with the application of cooperative learning jigsaw type on introductory subjects of economics and business class X students Accounting 3 SMK Sejahtera Surabaya academic year 2016/2017.

\section{METHOD}

This research uses Classroom Action Research type. Classroom action research is a type of research by taking certain actions to improve the learning process in the classroom. Wiriaatmadja (2009:3) suggests that classroom action research is how a teachers can organize the conditions of their learning practices, and learn from their own experiences. They can try an idea of improvement in their learning practices, and see the real effect of that effort.

This study is a Classroom Action Research which is implemented in 2 cycles. This classroom action research procedure has four stages in each cycle, ie action planning, action, observation, and reflection.

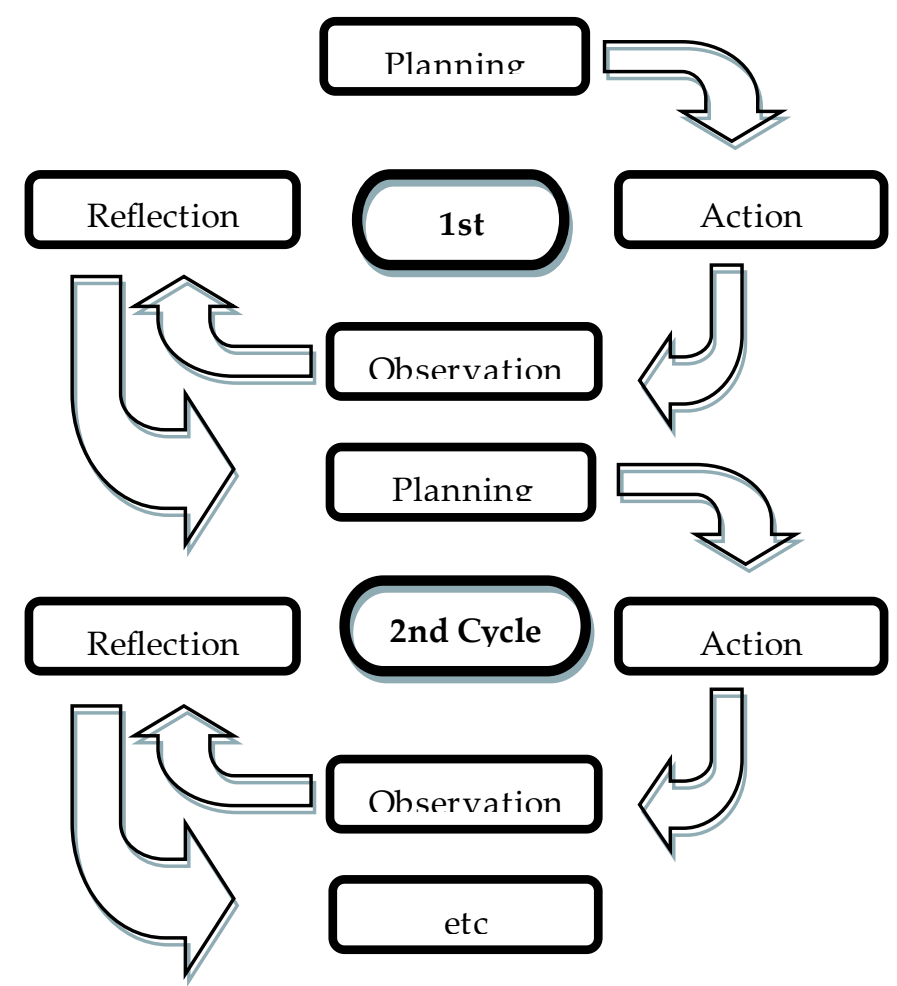

Figure 1.Classroom Action Research Cycle (Arikunto, 2010:137)

Subjects to this classroom action research were students of class X Accounting 3 SMK Sejahtera Surabaya which amounted to 37 students consisting of 5 male students and 32 female students with an average age of 16 years. This research was conducted at SMK Sejahtera Surabaya.

Data collection techniques are: (1) Initial condition data, where the researcher already has a list of task values and daily test of students obtained when conducting preliminary study at the school. (2) Data on student learning outcomes taken using the task and post test.The assignment is in the form of application of jigsaw type cooperative learning model that is divided into several homogeneous groups which then will 
prepare concept maps according to their area of expertise and applied when doing heterogeneous group tasks. Post test is given at the end of each cycle as an evaluation and is used as a student's cognitive ability data. Students who are active in teaching and learning activities will get additional grades and are used as affective student data. Discussions by each group will affect the value of each group and used as students' psychomotor ability data. (3) Data on student activities during teaching and learning activities took place by using observation sheets of student activities on the learning process that consists of aspects of sup porting learning and aspects that do not support learning. This data is taken every teaching and learning activities took place by researchers and teachers.

Analysis of this data using simple statistics, namely:

(1) data analysis of student activity observation results

$$
\mathrm{P}=\frac{\mathrm{f}}{\mathrm{N}} \times 100 \%(\text { Indarti, 2008:26) }
$$

Where :

$\mathrm{P}=$ percentage of occurrence frequency occurring

$\mathrm{f}=$ number of student activity that appear

$\mathrm{N}=$ total activity count

(2) data analysis of student learning outcomes

$$
\mathrm{P}=\frac{\sum \text { student who reach KKM }}{\sum \text { student }} \times 100 \%
$$

Where :

$\mathrm{P}=$ percentage of success

\section{RESULT, DISCUSSION, AND CONCLUSION}

Based on the results of research conducted by the researcher at SMK Sejahtera Surabaya, on May 10, 2016 and May 17, 2016. On May 10, 2016 carried out the first cycle, and on May 17, 2016 implemented the second cycle. The results of this study are as follows.

Student observation activities carried out during the learning process takes place.In this study, observations conducted by observers who help researchers in conducting research, namely Angga Juliyanto, S. Pd as an accounting teacher.

The rate of student activity in the learning process of cycle I is:

$$
P=\frac{32}{42} \times 100 \%=76,19 \%
$$

With percentage of success:

$0 \%-25 \% \quad$ declared less

$26 \%-50 \%$ declared sufficient

$51 \%-75 \%$ declared good

$76 \%-100 \%$ declared very good

Based on the above results obtained student activity $76.19 \%$ and declared very good. But these results have not met the success indicator of research that is above $80 \%$. While classical mastery in the process of learning cycle I is: 


$$
P=\frac{24}{37} \times 100 \%=64,86 \%
$$

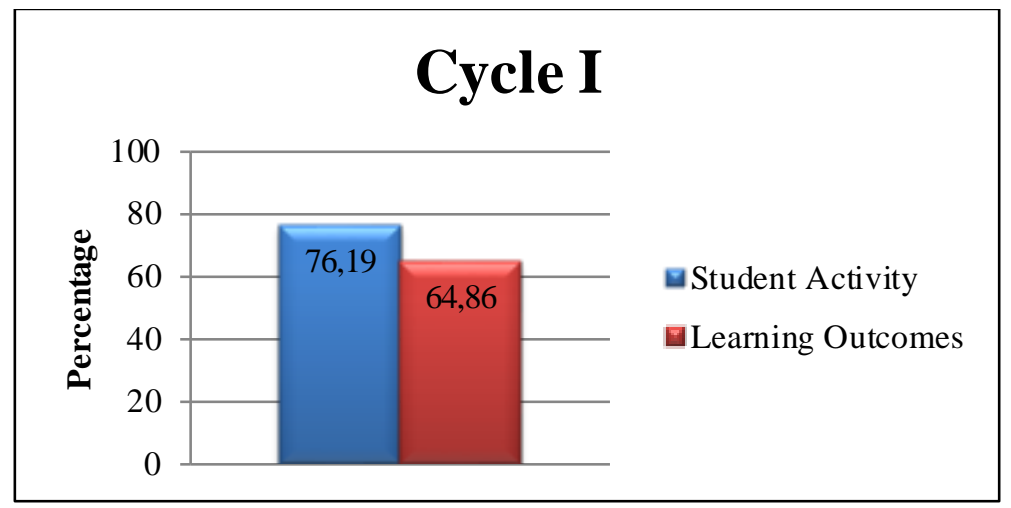

Figure 1. Result of Cycle I

From the result of the research, the students who got the score above KKM ( $\geq 75)$ were 24 students with $64.86 \%$ completeness and the students who got the score below KKM $(\leq 75)$ were 13 students with the percentage of $35.14 \%$. This shows that the classical completeness in cycle I has not reached the indicator of success because the percentage of classical completeness has not reached above $80 \%$.

To correct the deficiencies that existed in cycle I, the research continued on cycle II.The success rate of student activity in cycle II is:

$$
\mathrm{P}=\frac{36}{42} \times 100 \%=85,71 \%
$$

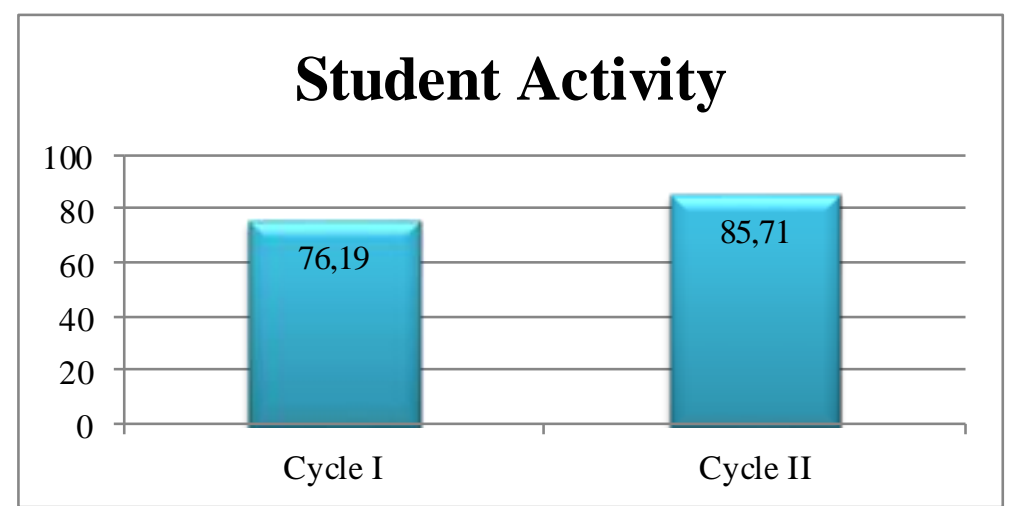

Figure 2. Result of Student Activity Cycle I and II

Based on the above results obtained student activity $85.71 \%$ and declared very good.Student activity increased from cycle I by $76,19 \%$ to $85,71 \%$ in cycle II.Thus the results have met the success indicator of research that is above $80 \%$.

While classical mastery in the learning process of cycle II are:

$$
P=\frac{30}{37} \times 100 \%=81,08 \%
$$




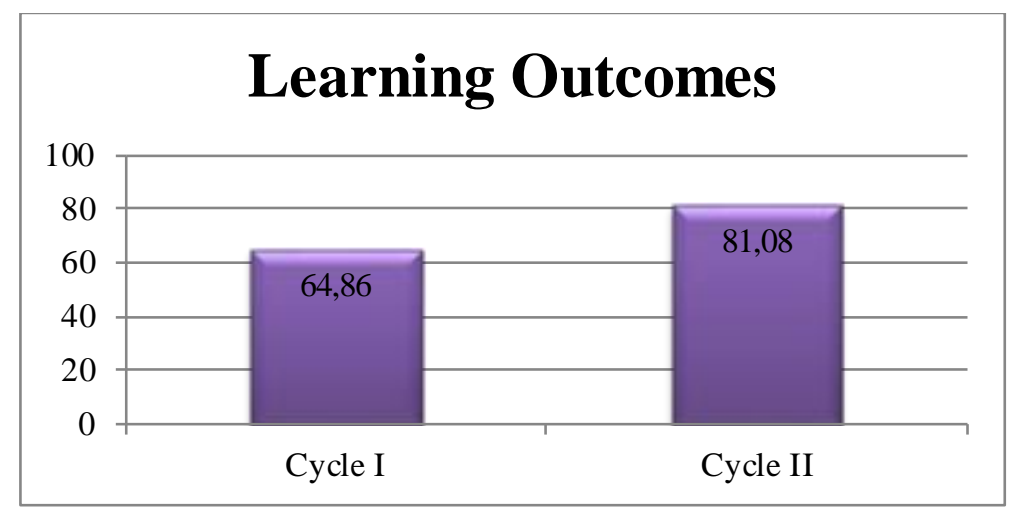

Figure 3. Result of Learning Outcomes Cycle I and II

From the results of the research above shows that students who score above KKM ( $\geq 75)$ as many as 30 students with a percentage of completeness $81.08 \%$ and students who score below $\mathrm{KKM}(\leq 75)$ as many as 7 students with percentage $18.92 \%$. This show s that students' mastery improved from cycle I of $64.86 \%$. Classic completeness has been achieved in cycle II because the results have met the success indicator of research that is more than $80 \%$.

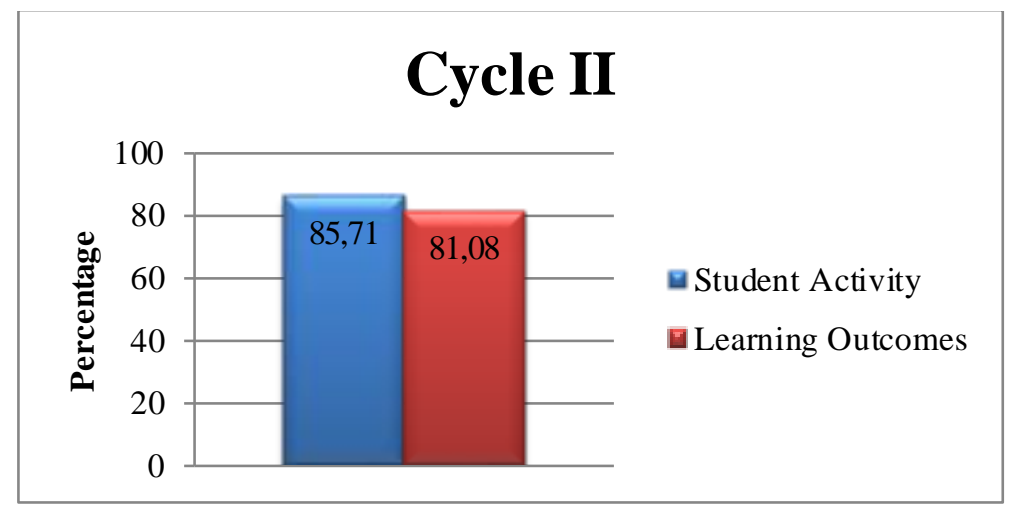

Figure 4. Result of Cycle II

Based on the results of research can be seen that student activity on the first cycle is considered very good because it reached $76.19 \%$. How ever, these results have not reached the success indicator of research that is more than $80 \%$.In addition, there are still some deficiencies in the activities of students cycle I, among others, students have not understood how the model of cooperative learning jigsaw type is applied so that students are less conditioned theirself on the learning process.To improve the deficiencies in cycle I, the research on the learning process continued in cycle II.

In the second cycle of student activity is very good because it has reached $85.71 \%$. This shows that student activity has increased in cycle I by $76.19 \%$ to $85.71 \%$ in cycle II with an increase of $9.52 \%$. That matterin accordance with the opinion of Dimyati and Mudjiono (1994: 152) that one of the goals of teaching in the groupis to provide opportunities for each of the self to develop problem-solving skills. The success of the Jigsaw type coopearative learning is also supported by Perkins opinions (2001: 111) which shows that technique Jigsaw type cooperative learning can help students understand learning materials, learning becomes more efficient, and can be improve student learning outcomes.

Student classical completeness value from cycle I to cycle II has increased. In the first cycle students mastery reaches only $64.86 \%$ and declared high, then on the second cycle has increased up to $81.08 \%$ and declared very high. Thus the mastery of students in a classical increase of $16.22 \%$. 
The results obtained in this study are in line with the research conducted by Hertiavi, et al with the title Application of Cooperative Learning Model Jigsaw Type for Improving Student Problem Solving Ability in SMP that there is an increase in the results of physics learning. Average student learning outcomes in the first cycle of 68.32 , second cycle of 73.61, and the third cycle of 83.84. Thus it can be concluded that in that study the application of jigsaw type cooperative learning model can improve student learning outcomes in physics subjects.

Because in the second cycle students' activities and classical completeness of students have reached the indicators of research success which is more than $80 \%$, it can be concluded that the application of the jigsaw type cooperative learning model can improve student learning outcomes in class $\mathrm{X}$ introductory economics and business. Thus, the research conducted until second cycle because the objectives of this study have been achieved in the second cycle.

Based on the results of research and discussion that includes student activities and learning outcomes in the Application of Cooperative Learning Model Jigsaw Type to Improve Learning Outcomes Introduction Economics and Business Students Class X Accounting 3 SMK Sejahtera Surabaya, the results obtained as follows. In cycle I, student activity has not succeeded in applying jigsaw type cooperative learning model on economic and business introduction subject. While on the second cycle of student activity succeeded in applying jigsaw type cooperative learning model on introductory subjects of economics and business students of class X Accounting 3 SMK Sejahtera Surabaya. The result of student learning increase in applying jigsaw type cooperative learning model on introductory subjects of economics and business class $\mathrm{X}$ Accounting 3 SMK Sejahtera Surabaya. Thus it can be concluded that the jigsaw type of cooperative learning model can increase student activity and learning outcomes.

After the implementation of the study, the teacher should use a learning model that is in accordance with the learning material. By using the appropriate learning model, it will be able to increase students' motivation to condition themselves well during the learning process. Thus, student activities will increase and help students to better understand the material being taught so that student learning outcomes can increase significantly.

\section{REFERENCES}

Arikunto, S. (2010). Prosedur Penelitian Suatu Pendekatan Praktik (Edisi Revisi 2010). Jakarta: Rineka Cipta.

Dimyati \&Mudjiono (1994). Belajar dan Pembelajaran. Jakarta: Direktorat Jenderal Pendidikan Tinggi Departemen Pendidikan dan Kebudayaan.

Hamalik, O. (2008). Pendidikan Guru Berdasarkan Pendekatan Kompetensi. Jakarta : Bumi Aksara.

Hertiavi, M.A., et al. (2010). Penerapan Model Pembelajaran Kooperatif Tipe Jigsaw untuk Peningkatan Kemampuan Pemecahan Masalah Siswa SMP. Jurnal Pendidikan Fisika Indonesia, 6, 53-57.

Indarti, T. (2008). Penelitian Tindakan Kelas (PTK) dan Penulisan Ilmiah. Surabaya: Lembaga Penerbitan Fakultas Bahasa dan Seni Universitas Negeri Surabaya.

Isjoni. (2010). Cooperative learning. Yogyakarta: Pustaka Pelajar.

Janah,I.I.N. \& Subroto,W.T. (2019). Comparison of cooperative learning models with inquiry on student learning outcomes. International Journal of Educational Research Review,4(2),58-62.

Perkins, D V. (2001). A "Jigsaw Classroom" Technique for Undergraduate Statistics Courses. Journal of Teaching and Psychology. 28: $111-113$. 
Rokhmah,N.F.\& Subroto,W.T. (2019). Application of cooperative learning Jigsaw type to improve learning outcomes of economic introduction and business. International Journal of Educational Research Review,4(2), 238-244.

Sanjaya, W. (2006). Strategi Pembelajaran. Jakarta: Kencana Prenada Media Group.

Suprijono, Agus. (2011). Model-model Pembelajaran. Jakarta: Gramedia Pustaka Jaya.

Wiriaatmadja, R. (2009). Metode Penelitian Tindakan Kelas. Bandung: PT Remaja Rosdakarya. 